\title{
Flow Direction and Source of Recharge of the Groundwater in North Kordofan and West White Nile Area, Sudan
}

\author{
Mohamed A. El Hadi ${ }^{1 *}$, El Nazeer G. Elseed ${ }^{2}$, Asim A. Elmansour $^{3}$ \\ ${ }^{1}$ Department of Earth Sciences, Faculty of Science, University of Gezira, Medani 21113, Sudan \\ ${ }^{2}$ Secretary for Academic Affairs, College of El Imam El Hadi, Umdurman 14411, Sudan \\ ${ }^{3}$ Department of Geology, Faculty of Science, University of Elobeid, Elobeid 51111, Sudan
}

Corresponding Author Email: umdaballo63@gmail.com

https://doi.org/10.18280/eesrj.070203

Received: 16 December 2019

Accepted: 22 April 2020

\section{Keywords:}

el kheiran, direct infilteration, static water level, subsurface flow, umm rawaba

\begin{abstract}
The aim of this study is to examine the flow directions and recharge potentiality of groundwater in the study area. Spatial changes on groundwater depths, elevations above mean sea level and salinity were signed on contour maps, and used to deduce a simplified model for groundwater flow. The results show that depths to groundwater increase from the northwest to the southeast; shallow depths less than $20 \mathrm{~m}$ were recorded in the extreme northwestern parts, whereas deeper depths, exceed $100 \mathrm{~m}$ were encountered around Umm Rawaba, next to Khor Abu Habil; from the static water elevations a higher value of about $470 \mathrm{~m}$ is found around El Kheiran area and a lower value of $330 \mathrm{~m}$ in the southeast; contours of the water levels indicate that groundwater generally flow from the north, northwest and the west to the east and southeast, and from the White Nile towards J. Kon. According to these results, two sources of recharge were itemized: recharge by direct infiltration through the sandy cover and recharge by subsurface inflow. The hydraulic gradient, presence of fresh groundwater in the northwestern parts and increase of salinity down gradient indicate that the northwestern parts are the main sources of recharge in the area. The abve results may be useful in future modelling, for safe exploitation of groundwater in the area.
\end{abstract}

\section{INTRODUCTION}

The area under the consideration lies in Central North Kordofan and West White Nile areas (Figure 1). The study area is considered as a part of the Sudanese Rift Basins which are developed as a part of Central African Rift System (CARS). These rifts extend from the western boundaries of the Sudan to the eastern boarders with Ethiopia [1]. Two groundwater basins included in the study area; Bara Basin in the west and Kosti basin in the eastern. EL Tayeb [2] divided Bara Basin into three sub basins and Kosti Basin into two sub basins (Figure 2).

Over the course of half a century, many studies have been conducted including the study area; most of them have focused on geological and hydrogeological conditions over whole Kordofan province. They present the basic data on the climatic conditions, geological aspects, groundwater occurrence, socio-economic characteristics, and possible extraction of groundwater. Examples for these studies are found in: Rodis et al. [3], Hunting Technical Services Ltd. [4], Ali [5], Geotehnika [6], Mohamed, Farwa and El Nazeer [7], Geotehnika [8], IFAD [9], El Tayeb [2], El Mansour [10], Abbashar [11], Dahab [12]. Few studies have shown an interest in the structural and tectonic aspects via some geophysical investigations, those are: Mitwali [13], Ali and Whitely [14], Mohamed, Salama [1], Farwa and El Nazeer [7], El Mansour [10], Abbashar [11], and En Nair [15].

Most of these studies are scattered and preserved as file reports within the archives of institutions related to water resources; the rest are unpublished university theses. In the recent decades extensive exploration activities were carried out in the study area as a response to the increasing demands for groundwater in the area.

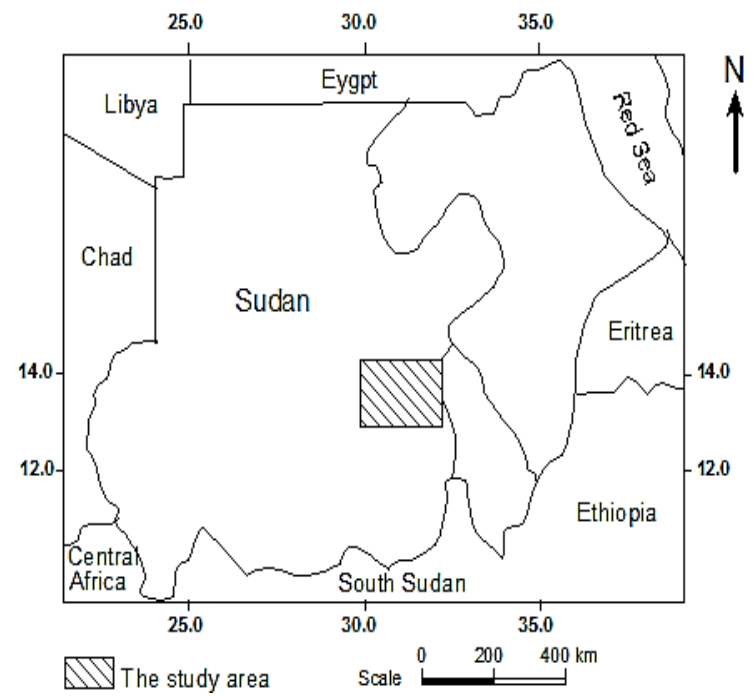

Figure 1. Location of the study area

The present study aims to assess groundwater flow and recharge Potentiality in the study area by means of analyzing the existing borehole reports; this is benefit for future studies and safe groundwater development in the area. 


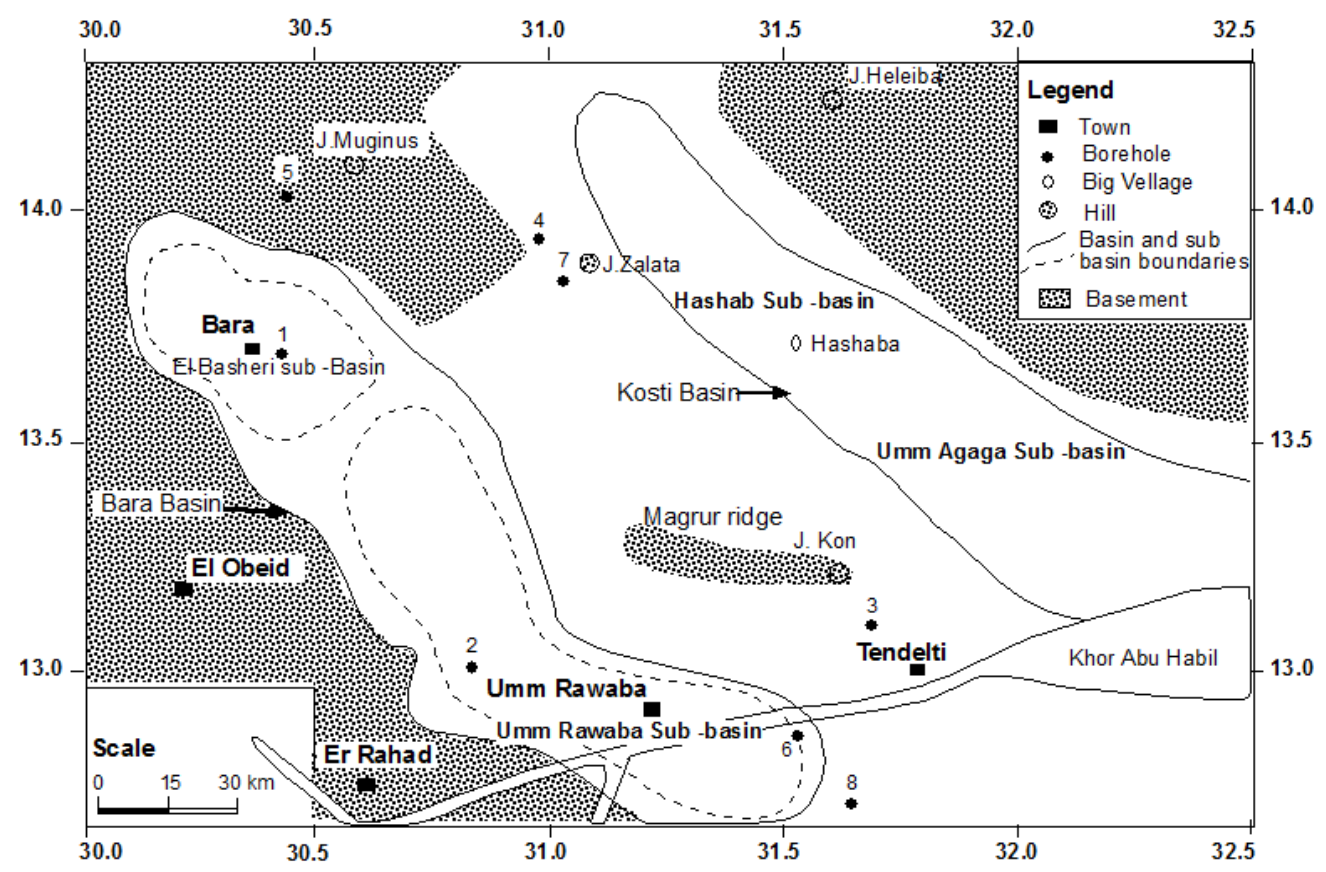

Figure 2. Sedimentary basin and sub-basins in the study area (modified from El Tayeb 2000)

\section{REGIONAL GEOLOGY}

The oldest geological unit in the area is the Basement Complex rocks. They are assumed to be mainly of PreCambrian age [16]. The Basement rocks are overlain by the Nawa Formation in areas around Er Rahad, or by the Mesozoic sediments of the Nubian Sandstone Formation in the base of the basins. They crop out in the area as form of Jebels (Hills) such as J. Mugunis, J Zalata, J. Heleiba and J. Kon. The Mesozoic sediments of the Nubian Sandstone Formation are overlain by the Umm Rawaba Formation. The thickness of the Nubian sediments reaches $700 \mathrm{~m}$ in Kordofan area [6]. Umm Rawaba Formation represents the main sedimentary unit in the area. It is mainly composed of unconsolidated sediments of sands, granules and clays. The geophysical investigations indicate that the thickness of the formation exceeds $500 \mathrm{~m}$ at Bara [10]. It is overlain by the superficial deposits of sand dunes (Qoz sands). The thickness of all unconsolidated sediments in the central part of the Bara Basin attains $1.4 \mathrm{~km}$ [5].

\section{MATERIALS AND METHODS}

In this study borehole data from about 124 bores were used (Figure 3). This data includes borehole locations (coordinates), water depths and elevations of the borehole points, based on the mean sea level (m. s. 1), and TDS of the groundwater (Table 1).

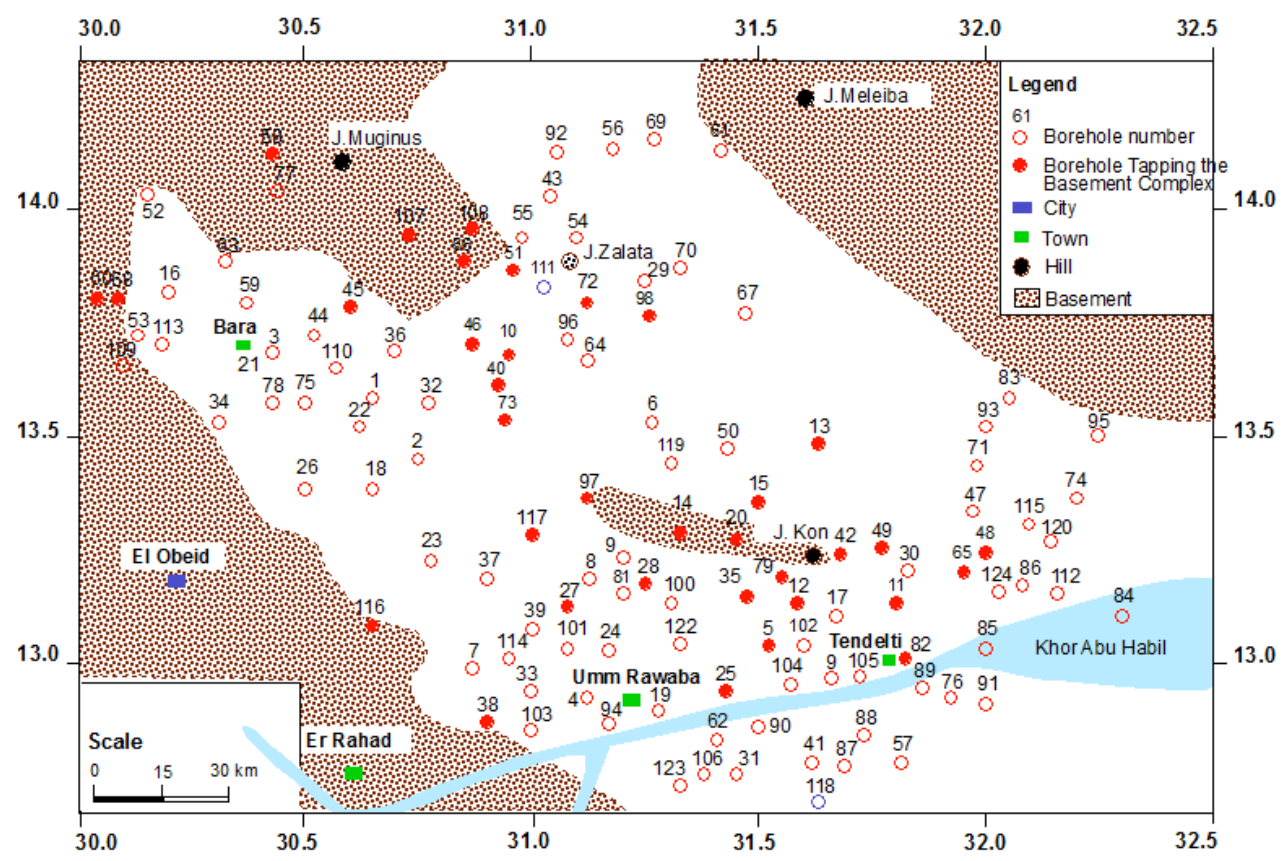

Figure 3. Boreholes locations in the study area 
Table 1. Summary of 124 boreholes data in the study area

\begin{tabular}{cccccc}
\hline G.S. Elev.(m) & Well Depth (m) & D. to B.C. $(\mathrm{m})$ & S.W.L $(\mathrm{m})$ & EC $\mu$ mohs & T.D.S mg/l \\
$395-515$ & $76-426$ & $76-198$ & $20-107$ & $600-7286$ & $118-5100$ \\
\hline
\end{tabular}

G.S. Elev.: Ground Surface Elevation, D. to B.C: Depth to Basement Complex,

W D: Water Depth, EC: Electrical Conductivity, TDS: Total Dissolved Solids

The depth to the groundwater in a borehole is usually measured from ground surface. In this study the depths to water table of more than 70 boreholes were measured and used in construction of hydrogeological contour maps. The static water elevation has been obtained by subtraction of water depth in the borehole from the borehole elevation. Eq. (1).

$$
\text { S.W.L }=\text { B.H.elev. }-W D
$$

where:

S.W.L $=$ Static Water Level a,m,s,l in meters

B.H, elev, = Borehole elevation a.m.s.l in meters

W.D. = Water Depth reference to ground surface in meters

The water depths and static water tables were used to create four hydrogeological counter maps to delineate the flow direction and source of recharge of the groundwater in the study area.

Freehand 9.02 is software mainly used for drawing purpose. It is used for drawing and modifying hydrogeological sections and maps in form of images.

The depth to the groundwater in a borehole is usually measured from ground surface. In this study the depths to water table of more than 70 boreholes were measured and used in construction of hydrogeological contour maps. The static water elevation has been obtained by subtraction of water depth in the borehole from the borehole elevation as follow:

Static water level = borehole elevation (m. s. l) - water depth in the borehole reference to ground surface.

The water depths and static water tables were used to create four hydrogeological counter maps to delineate the flow direction and source of recharge of the groundwater in the study area.

Freehand 9.02 is software mainly used for drawing purpose. It is used for drawing and modifying hydrogeological sections and maps in form of images.

\section{RESULTS AND DISSCUSION}

\subsection{Static water level contours and flow direction}

The contour maps of groundwater levels in the upper aquifer (Figure 4) show variations in water depth. The depths to water level depend on the topography and proximity to recharge sources. Generally, the depths to the groundwater increase from the northwest to the southeast directions in the area. Shallow depths of less than $20 \mathrm{~m}$ are recorded around El Kheiran Area, whereas deeper depths which exceed 100 $\mathrm{m}$ are encountered around Umm Rawaba, giving a sense of flow from the northwest to the southeast. On the other hand, the water depths in the lower and deep aquifers (Figure 5) manifest a depressed area extended north-south passing $\mathrm{J}$. kon, whereas the depth increase from the northwest and southeast towards this area. This suggests that flow of ground water is from the White Nile area and from the northwestern region towards the depressed area

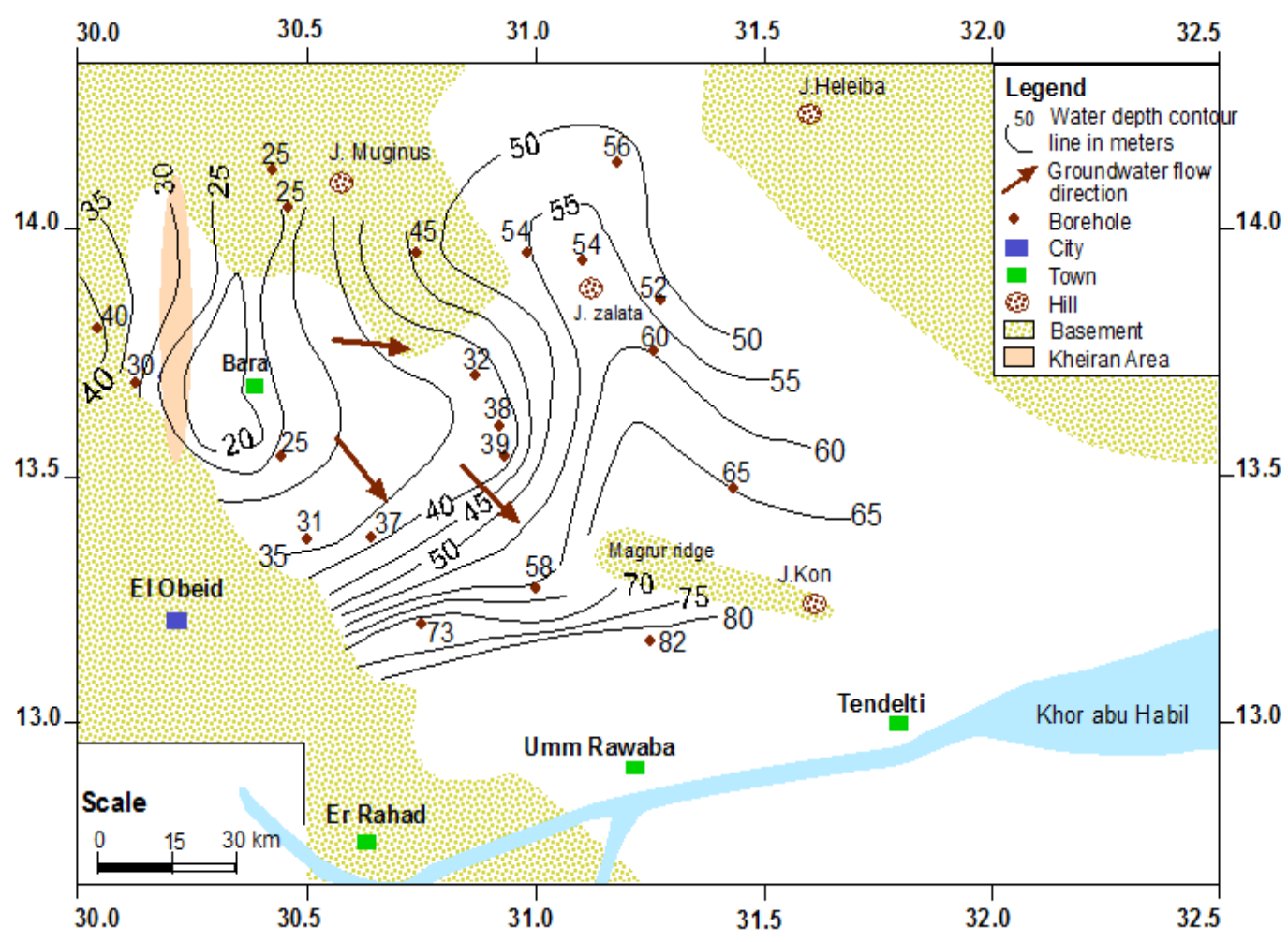

Figure 4. Depths to groundwater surface of the upper aquifer 


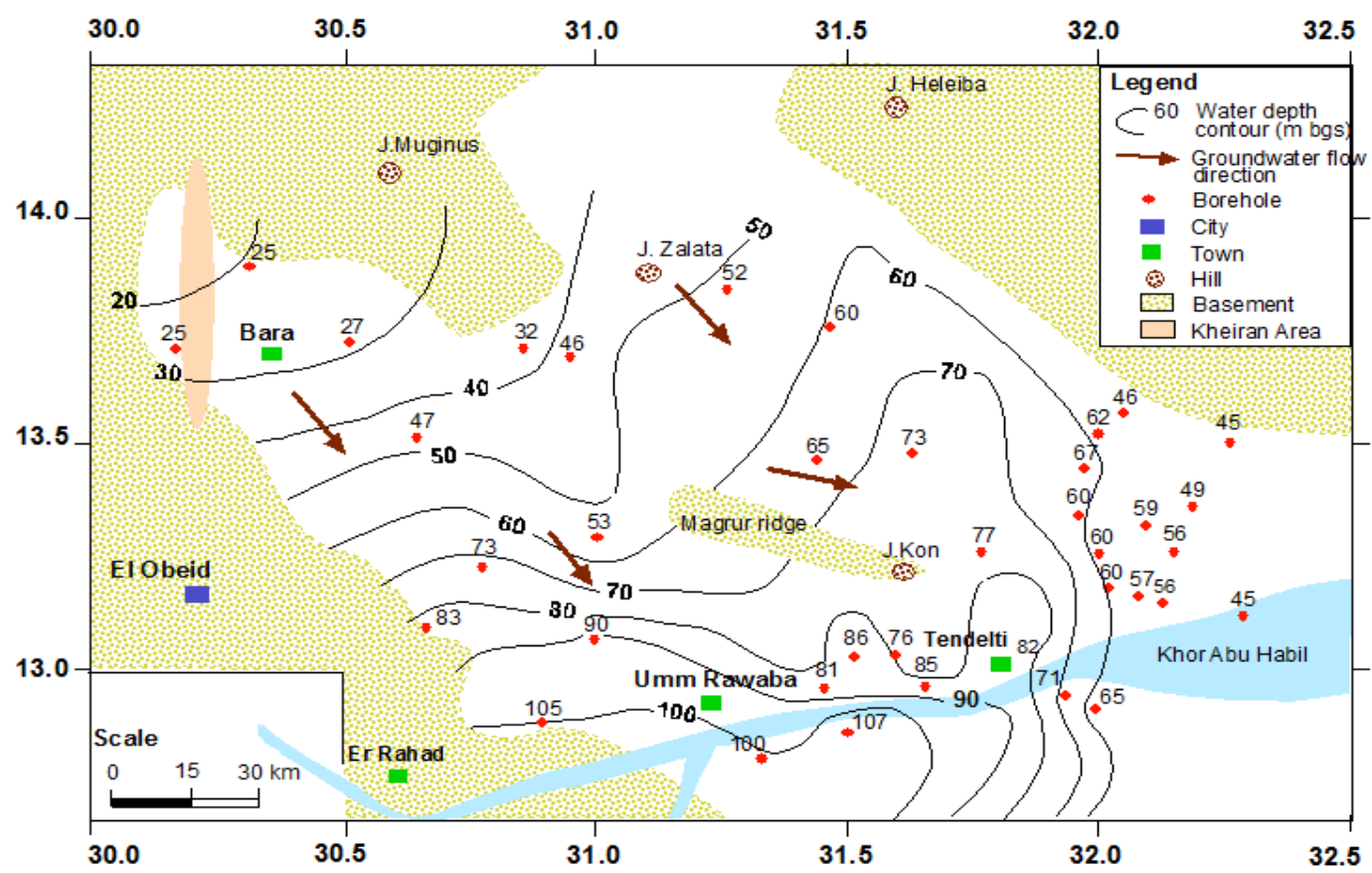

Figure 5. Depths to groundwater surface of the lower and deep aquifers

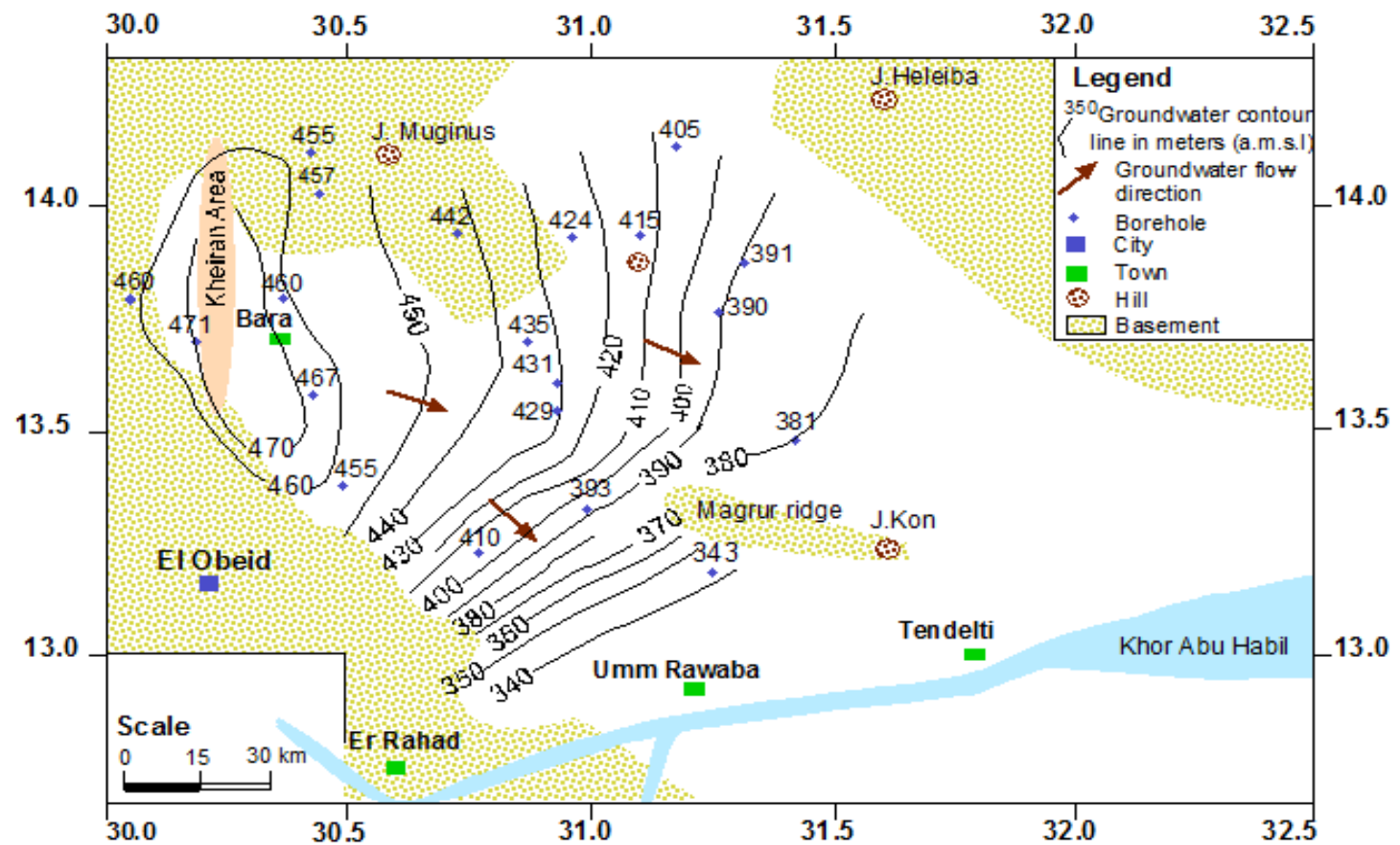

Figure 6. Regional variations in the static water level of the upper aquifer

Contours of groundwater elevation in the upper aquifer (Figure 6) vary from $470 \mathrm{~m}$ to about $330 \mathrm{~m}$. The higher value is recorded around El Kheiran Area whereas, the lower value is encountered east Jebel Kon. The hydraulic gradient delineates flow direction of the groundwater from the northwest to the southeast; this confirms what was inferred from contours of the depth to water in the area (Figure 4).

Contours of groundwater elevation in the lower and deep aquifers (Figure 7), encountered the higher value north of Bara while the lower value is recorded around Tendelti. Groundwater elevations indicate a hydraulic gradient and therefore a general flow from the northern, northwestern and the western parts towards the eastern and southeastern areas and from the White Nile towards J. Kon (Figure 7). These facts correspond to what is derived from the water depths maps
(Figure 6).

\subsection{Recharge sources}

Important evidences for recharge to aquifers in the area can be indicated by the following:

(1) Fresh groundwater in the northwestern and western areas and increase of salinity down gradient in the area.

(2) Long term groundwater levels consistency in spite of pumping in the northern, northwestern and western parts.

(3) Isotopes data (IFAD, 1993) indicated the presence of recent waters along the Kheiran (northwestern) area in addition to seasonal fluctuations of groundwater levels.

Two types can be itemized as possible sources of recharge: 


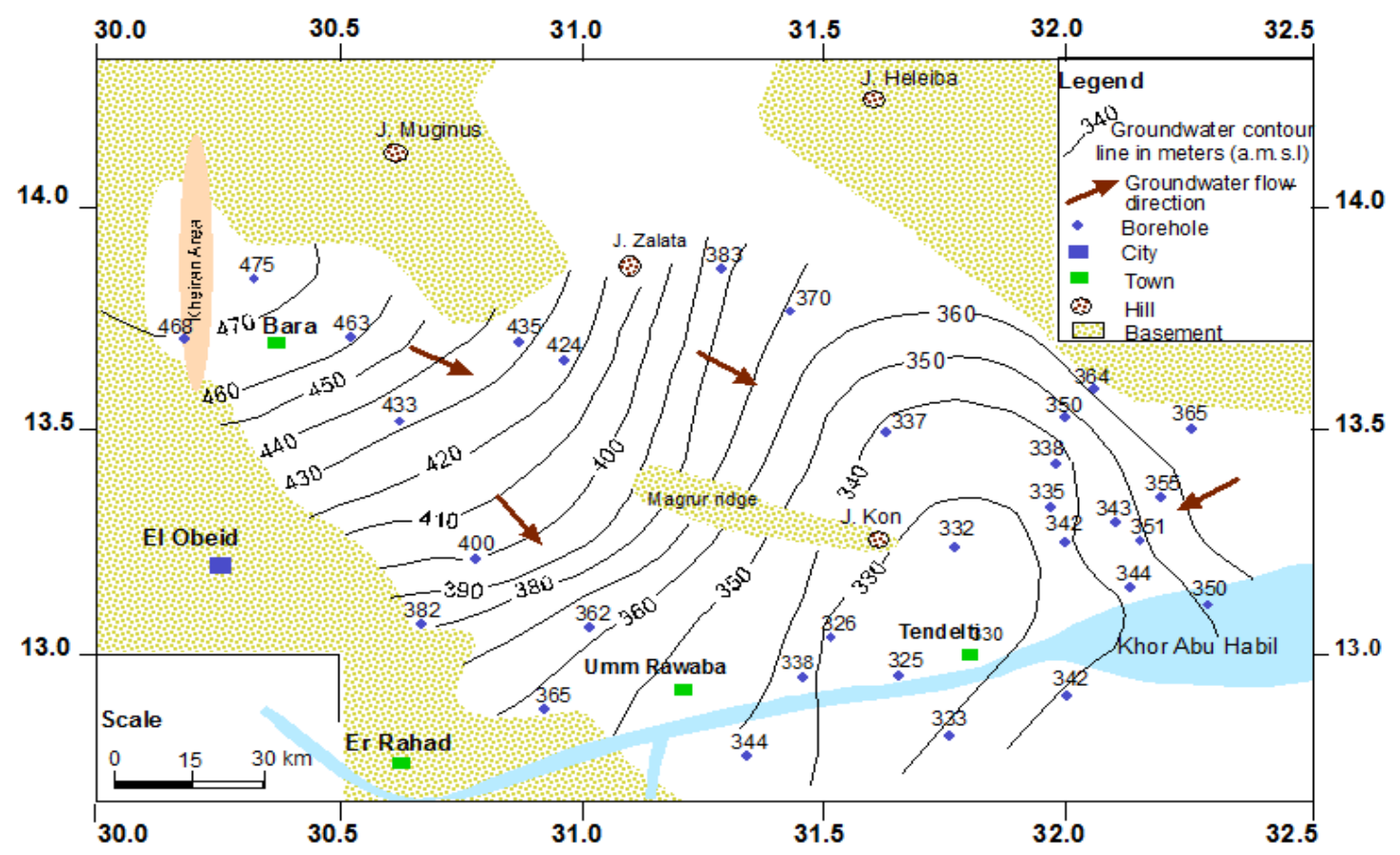

Figure 7. Regional variations in the static water level of the lower and the deep aquifers

Recharge by Direct Infiltration: direct infiltration of rainwater represents a contributing source of the groundwater recharge, but it seems to be unlikely in the study area because of low annual rainfall (200- $450 \mathrm{~mm} / \mathrm{y})$ compared to the higher evapotranspiration rate $(2500 \mathrm{~mm} / \mathrm{y})(\mathrm{El}$ Tayeb, 2000). The rainwater infiltration takes place mostly in the northwestern part of the area. It is enhanced by the dominance of the Qoz sands which characterized by good sorted sediments and high porosity and permeability. The direct infiltration may occur only in the upper aquifer and specifically around El Kheiran and Bara areas where the static water level is shallower. Therefore, regional recharge by direct infiltration of rainwater does not exist in the southern part of the study area where the static water level is very deep.

Another form of recharge by the infiltration exists as a result of streams flow during the rainfall season. It is supposed to take place along the WNW boundary of Bara Basin. This boundary lies between El Obeid and Bara and extends for some kilometers along the boundary between the Basement and the sedimentary rocks. Small water coarses and streams drain the higher plateau of J. Kordofan and disappear north of El Obeid into the sand dunes. In this area the water coarses and streams may replenish the groundwater of the upper aquifer.

What is noticeable that no recharge from Khor Abu Habil is observed, in spite of that it is the major stream in the study area. This can be justified as due to the thick impermeable clay dominating the sedimentary sequence in the area.

Recharge by Subsurface Inflow: The recharge by subsurface inflow takes place at two parts in the study area. The first one lies to the north and bounded in the east and west by the Basement rocks while the second lies to the northwest and forms a curve extending from the north (Geregikh) passing to the west and terminates south of the Kheiran area. The first locality may replenish groundwater of the lower aquifer from the Nubian Basin lying north of the area by subsurface inflow. Other form of recharge by the subsurface inflow was recorded in the eastern part of the study area west of the White Nile. The evidence of this recharge was detected from the reversal flow direction from White Nile in the east towards J. Kon (Figure
6); that means the White Nile represents the eastern hydrogeological boundary of the basin. The White Nile runs for hundreds of kilometers through an area covered by both Basement and sedimentary rocks; but it seems that limited area is covered by the sedimentary rocks which may allow for direct connection between surface and groundwater.

\section{CONCLUSIONS}

The flow and recharge of groundwater in the study area were assessed on the basis of variations in the static water levels and water salinity. The systematic change of these variations manifest a general flow directed from the northwest to the southeast. Reversal of the flow at the extreme eastern part of the study area indicate that only a limited recharge is coming from the White Nile which due to the hydrogeological conditions at that parts. Increase of salinity downwards the hydraulic gradient also confirm the fact of the limitation of recharge from the eastern boundary of the study area. The thick permeable sandy cover can allow appreciable amount of recharge to the aquifer system in the area. Accurate and disciplined investigations including estimation of the hydraulic characteristics of the geological formations and the rates of the rainfalls in the area are reccommended in the future for a good determination of the recharge potentials.

\section{ACKNOWLEDGMENT}

Acknowledgement is to all institutions, agencies and individuals who help anyway in completing this work.

\section{REFERENCES}

[1] Salama, R.B. (1985). Buried troughs grabens and rifts in Sudan. Journal of Africa, Earth Sciences, 3(3): 381-390. https://doi.org/10.1016/0899-5362(85)90012-0 
[2] El Tayeb, O.A. (2000). Groundwater hydrogeology of west-Central Sudan, Hydro-chemical and Isotopic Investigation, Flow Simulation and Resources Management. Ph.D. Thesis. Berlin.

[3] Rodis, H.G., Hassan, A., Whadan, L. (1965). Groundwater Geology of Kordofan Province, Sudan. USGS Numbered Series. https://doi.org/10.3130/wsp1757J

[4] Hunting technical services limited. (1970). A hydrogeological survey in eastern Kordofan Province, Sudan. Report submitted to Rural Water Corporation, Khartoum (unpublished).

[5] Ali, H.O. (1983). Numerical analysis of groundwater resources in the Bara basin, Sudan. International Conference on Groundwater and Man, Sydney.

[6] Geotehnika, (1985). El Obeid water supply project, Feasibility study of groundwater resources. Master report (unpublished), National Water Administration, Ministry of Energy and Mining, Khartoum, Sudan.

[7] Mohamed, A.I., Farwa A.G., El Nazeer, G.E. (1986). A geological and Geophysical and Hydrogeological Investigation in Northern Kordofan, Department of geology, University of Khartoum, Sudan (unpublished).

[8] Geotehnika, (1988). El Obeid water supply project, exploration of groundwater resources (unpublished), National Corporation for development of rural water resources, Ministry of Irrigation and water resources. Khartoum, Sudan.

[9] IFAD (1993). Northern Kordofan Rural Water Development Project, Special Identification Mission
Reports (unpublished), Ministry of irrigation and Water Resources, Khartoum, Sudan.

[10] El Mansour, A.A. (2005). Hydrogeological study of western Basin Northern Kordofan State. M. Sc. Thesis (unpublished) University of Kordofan, Sudan.

[11] Abbashar, A.A. (2005). Geophysical exploration for groundwater in crystalline rocks, El Obeid area, North Kordofan, Sudan Sc. Thesis, School of Applied Science and Technology, Al Neelin University (un published).

[12] Dahab, M.A. (2007). Assessment and evaluation of groundwater in Abu Habil water shed, North Kordofan state, western Sudan. M Sc. Thesis (unpublished), School of Applied Science and Technology, Al Neelin University.

[13] Mitwali, M.A. (1969). Interpretation of low gravity anomaly in Northern Kordofan, West Sudan. Bull. Geofis. Theoreti App., 11(41-42): 119-125.

[14] Ali, H.O., Whitely, R.J. (1981). Gravity exploration for groundwater in the Bara Basin, Sudan, Geoexploration, 19(2): 117-141. https://doi.org/10.1016/00167142(81)90025-9

[15] En Nair, G.G. (2011). Resistivity study of the structural patterns in the area between Umm Rawaba and En Nahud Basins, North Kordofan state. M Sc. Thesis (unpublished), Department of Geology, Kordofan University, Sudan.

[16] Whiteman, A.J. (1971). The geology of the Sudan republic. Geological Magazine, 109(1). https://doi.org/10.1017/S0016756800042448 